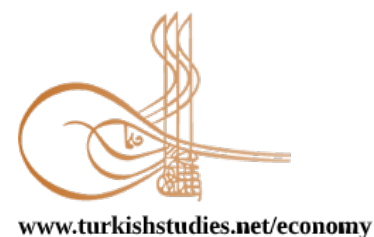

Turkish Studies - Economics, Finance, Politics

eISSN: 2667-5625

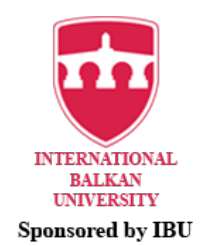

Research Article / Araștırma Makalesi

\title{
Otomatik Katılım Sisteminde Muhasebe İşlemleri ve Öğretmenlerin Sisteme Bakışına Yönelik Bir Analiz ${ }^{*}$
}

\author{
Accounting Procedures in Automatic Participation System and an Analysis of Teachers' \\ Perspective on the System
}

\author{
Yakup Ülker ${ }^{* *}$ - Harun Tat ${ }^{* * *}$
}

\begin{abstract}
Private Pension System which firstly comes into our lives and virtually began to register members on October 27,2003 has achieved a high growth since 2003. The system has had the biggest change since January 1,2017. On this date, 45 years old citizen of the Republic of Turkey in the public or private sector input into the system automatically performing employees. Thus, the Automatic Participation System (OKS) started. The reactions of the participants have been highly below the average. Leaving the system has happened in both the public and private sector. Although initially not enough, as time went on, serious increases occured in both savings and participants in the system through reforms. This system is a case of Private Pension practice. The purpose is to evaluate the funds (contributions) and make payments to the individual in a way to benefit from retirement. The funds provided here should be recorded regularly by the accounting department of the system and the funds evaluated with expert financiers should also be protected by keeping track of them. If registration procedures are not followed systematically deficits that will occur in time will make the system uncontrollable and the expected benefits will not occur. In the study, functioning, financing and financial highlights for evaluation and accounting practices of Private Pension System were mentioned and the perspectives of teachers who constitute an important population in our country were evaluated with a field research. In the study, the reasons of leaving the system have been determined and suitable solutions have been proposed. Since participants were not informed about the system before, they involved in the process without having information about funds. Therefore, the participants who were unaware of the interest -free funds left the system considering that their savings were used in interest-fund. Although state subsidy has been reacted positively by the participants, excluding the inflation rate from the process caused falling short of the expectations of persons. Automatic participation of the participants
\end{abstract}

\footnotetext{
* Bu çalışma Sivas Cumhuriyet Üniversitesi Sosyal Bilimler Enstitüsü, Muhasebe, Finans ve Bankacılık Ana Bilim Dalında, Ocak 2020'de kabul edilen, Dr.Öğr. Üyesi Yakup ÜLKER danışmanlığında Harun TAT'ın “Otomatik Katılım Sisteminde Muhasebe İșlemleri ve Öğretmenlerin Sisteme Bakıșına Yönelik Bir İnceleme” isimli Yüksek Lisans tezinden faydalanarak hazırlanmıştır.

** Dr. Öğr. Üyesi, Sivas Cumhuriyet Üniversitesi, İ̈BF, Bankacılık ve Finans Bölümü

Asst. Prof. Dr., Sivas Cumhuriyet University, Faculty of Economics and Administrative Sciences, Department of Banking and Finance

ORCID 0000-0002-3070-0521

yulker@hotmail.com

${ }_{* * *}$ Bilim Uzmanı, Sivas Cumhuriyet Üniversitesi, Sosyal Bilimler Enstitüsü

Master's Degree, Sivas Cumhuriyet University, Graduate School of Social

ORCID 0000-0002-0462-9733

haruntat@gmail.com

Cite as/ Atıf: Ülker, Y., Tat, H. (2020). Otomatik katılım sisteminde muhasebe işlemleri ve öğretmenlerin sisteme bakışına yönelik bir analiz. Turkish Studies - Economy, 15(2), 1001-1021. https://dx.doi.org/10.29228/TurkishStudies.42688

Received/Geliş: 29 March/Mart 2020

Accepted/Kabul: 20 June/Haziran 2020

Copyright (C INTAC LTD, Turkey

Checked by plagiarism software

Published/Yayın: 25 June/Haziran 2020

CC BY-NC 4.0
} 
without getting their opinions has also disturbed them. At the end of the study, it has been determined that demographical characteristics such as age, marital status and gender have no significant relationship with membership to the system. It has been revealed that state subsidy, tax advantage, second pension choice, support for economising, having the opportunity of receiving savings collectively have a significant relationship with membership to the system.

Structured Abstract: In our country, since incomes in working life will fall after retirement and people will desire to maintain same quality of life, as a second source of income Private Pension System came into effect in 2003. However, the participants did not react adequately to the system and there was a high rate of separation. Determining the reasons of the teachers who have a population of approximately one million working in this framework and leaving new regulations in this regard will help to achieve the desired success in the system. Considering the importance of the system for national economy, a study has been done and a questionnaire has been conducted on 235 teachers who work in Suşehri, Sivas to determine the reasons of leaving the system.

The new private pension system, also known as the automatic participation system, is an application that is of great importance for both fund size and number of participants. However, the decrease in the number of participants led to divergence from the targeted fund size. It is important to determine the reasons for the participants to leave the system, to prevent the separations by making the necessary corrections and to reach the desired fund size.

In our study, firstly, information about the structure, development and functioning of the private pension system, financial events and accounting practices for financing and evaluation is included. Then, the system's automatic participation system, changing state contribution, right of withdrawal, funds provided to participants and retirement period in the system were examined. The perspectives of the teachers, which constitute an important population in our country, were evaluated with a field study.

The data collection tool of the study was applied by a researcher with a face-to-face survey method to a total of 235 teachers working in the Suşehri district of Sivas province, with a total of 235 teachers. Firstly, the distribution of participants was determined by creating a frequency table according to their demographic characteristics. The knowledge levels and opinions of the participants about PPS were analyzed with the help of a cross table and using the chi-square independence test. In order to reveal the attitudes and behaviors of the participants towards the system, an evaluation was made using 15 expressions prepared in 5-point Likert type. The data obtained from the application was entered into the SPSS 22.0 package program and the data set of the research was created.

The findings of the research can be summarized as follows:

- $50.1 \%$ of the participants do not see the system as a good investment tool.

- Most of the respondents stated that age 56 is satisfactory for retirement.

- Although a second retirement income has been provided, the rate of those who think that they will not have a comfortable retirement is high.

- The ratio of those who think that OKS will not contribute enough to the country's economy has been considerably high.

- 82 per hundred people do not find the tax advantage sufficient

- Although most of the participants stated that state support is important, they stated that the support was insufficient to join the system.

- It shows that people whose marital status among the participants are married, continue their private pension insurance for investment purposes because their future concerns are higher.

- It was found that there was no relationship between gender and membership in the system.

- The high rate of withdrawal among people who have knowledge of the participants indicates that there is insufficient incentives, misinformation of the participants, or that the institutions in the system do not provide sufficient, correct and competent information.

In increasing interest in the system; thanks to the regulations, it is supported by incentives such as state subsidy and tax advantage as well as managing and promoting the system by experts. Also, increasing the retirement age can be said to be a reason of increasing interest. Nevertheless, it can be said that this participation is still not enough when compared to developed countries. Compared to Gross Domestic Product ratio of the pension fund in Turkey with other OECD countries remained at very low levels, it can be

Turkish Studies - Economy, 15(2) 
said that Turkey has a very big potential baout Private Pension. The funds provided through the system should be recorded regularly by the accounting department and the funds evaluated with expert financiers should also be protected by keeping track of them.

Systems implemented by states may not achieve sufficient success. Firstly, a feasibility study must be carried out in order to increase the success of the system. Thus, a new and more comprehensive study on these situations can be developed and the system can be updated by detecting missing or wrong sections in the implementation of the system. Automatic Participation System appeared on January 1,2017 with its new face, ignoring the expectations of the participants. However, the difference between the expected situation and the actual situation is serious. To be able to identify the reasons of this difference and produce a solution proposals, the results of the study applied to 235 participants can be summarized and expressed as follows;

- The arrangements made were not sufficient and in this case participants left the system.

- The system should be explained in detail by persons and organizations involved. Because the the inver invesparticipants make decisions with hearsay information.

- Automatic Participation of the system should be changed. Instead, encouraging new suggestions should be presented.

- Desensitisation on religious point of the participants about state subsidy is necessary and the interest free funds must be explained to the participants.

- Changes in state subsidy should be made depending on the increasing in inflation rate. In the period when the inflation rate is high the fact tahat the state subsidy remains constant poses a problem for the participants.

- Expectations should be more realistic

- The contribution of the system to the state economy and the investor should be emphasized

- Fund types should be explained to the participants since the participants do not have sufficient information about the funds.

- Arrangements about the cuts made to the participants who left the system before staying ten years should be made.

- Consultancy service should be provided continuously in order to manage funds well.

- An arrangement should be brought to the cuts from funds

- The fund sizes of Private Pension and Automatic Participatin Systems increase rapidly day by day. In this context, the funds that evaluated and recorded into the system and the transactions of accounting processes should be followed in accordance with the accounting rules and practices without any irregularity.

- Transparency on matters such as how funds collected in the system are evaluated by experts and how much income is earned must be maintained regulary.

After this study based on a certain segment and a certain region; To a larger extent, a research can be conducted to cover all members of the Ministry of Education. In addition, empirical studies can be conducted for private sector, bank sector or academicians' view of the system. Studies on the contribution of the Automatic Participation System to the country's economy can also be carried out and studies on this subject can be enriched.

Keywords: Private Pension System, Accounting Practices, State Subsidy, Social Security, Automatic Participation

Öz: İlk kez 27/10/2003'de fiilen üye kaydederek hayatımıza dâhil olan Bireysel Emeklilik Sistemi 01/01/2017 tarihinde, en büyük değişikliğini yaşamıştır. Bu tarihde 45 yaş altı Türkiye Cumhuriyeti vatandaşı olan kamu ya da özel sektör çalışanlarının sisteme girişi otomatik olarak gerçekleştirilmiştir. Böylece Otomatik Katılım Sistemi (OKS) başlamıştır. Meydana gelen bu değişikliğe katılımcıların vermiş olduğu tepki ise beklenilen düzeyin çok altında kalmıştır. Hem kamu sektöründe hem de özel sektörde sistemden büyük oranda çıkışlar meydana gelmiştir. Başlangıçta yeterli olmamakla birlikte zaman ilerledikçe reformlar yoluyla hem tasarruflarda ve hem de sisteme katılımda ciddi artışlar sağlanmıştır. Bu sistem bir özel emeklilik uygulaması durumudur. Burada amaç elde edilen fonların (katkı payları) değerlendirilerek emekliliğe faydası olacak şekilde bireye ödeme yapılmasıdır. Burada öncelikle sağlanan fonların, sistemin muhasebe departmanı tarafından düzenli olarak kayıt altına alınması ve uzman finansçılar ile değerlendirilen fonların da yine kayıtlar ile korunarak takip edilmesi gerekir. Eğer sistemli olarak kayıt işlemleri takip edilmez ise zaman içerisinde oluşacak açıklar sistemi kontrol edilemez hale getirecektir ve beklenen fayda 
oluşmayacaktır. Yapılan çalışmada bireysel emeklilik sisteminin işleyişi, finansmanı ve değerlendirilmesine yönelik mali olaylar ve muhasebe uygulamaları hakkında bilgilere yer verilerek bu sisteme, ülkemizde önemli bir nüfus kitlesini teşkil eden öğretmelerin bakış açıları bir saha araştırması ile (yüz yüze anket yöntemi) değerlendirilmiştir. Yapılan araştırmada katılımcıların sistemden çıkış sebepleri belirlenerek çözüm tavsiyelerinde bulunulmuştur. Katılımcılara sistem hakkında bilgilendirme yapılmadan sürece dâhil edilmesi sebebiyle katılımcılar fonlar hakkında bilgi sahibi değildir. Bu sebeple faizsiz fondan bilgisi olmayan katılımcılar sistemdeki birikimlerinin faizli fonda değerlendirildiğini düşünerek sistemden çıkmıştır. Devlet katkısı katılımcılar için olumlu karşılanmasına rağmen enflasyon oranının sürece dâhil edilmemesi kişilerin beklentilerinin karşılanmamasına sebep olmuştur. Katılımcıların fikirleri alınmadan sisteme otomatik dâhil edilmesi de katılımcıları rahatsız etmiştir. Yaş, medeni durum, cinsiyet gibi demografik durumların sisteme üyelik ile anlamlı bir ilişkisinin olmadığı belirlenmiştir. Devlet desteği, vergi avantajı, sistemin tasarrufa yardımcı olması, ikinci bir emeklilik seçeneği, birikimleri toplu olarak tahsil etme imkânı ile sisteme üyelik arasında anlamlı bir ilişkinin varlığı belirlenmiştir.

Anahtar Kelimeler: Bireysel Emeklilik Sistemi, Muhasebe Uygulamaları, Devlet Katkısı, Sosyal Güvenlik, Otomatik Katılım.

\section{Giriş}

Yaşlı nüfusun yükselişiyle beraber emekli sayısında artış meydana gelmiş bu artışın neticesinde de mevcut çalışanlardan elde edilen prim gelirleri sosyal güvenliğin finansmanını sağlamada yetersiz kalmıştır. Çalışanların gelecekle alakalı endişeleri, çalışma hayatında yapacakları az miktardaki tasarruflarla emekli olduklarında ikinci bir ücret geliri alma firsatı, emniyetli ve şeffaf bir ortamda yatırım yapabilme olanağı ve kamu otoritesince sağlanan destek ile birlikte Bireysel Emeklilik Sistemi geliştirilmiş ve hızla yaygınlaşmıştır. Zaman ilerledikçe meydana gelen gelişmeler bu sistemde yenilik yapılması ihtiyacını gündeme getirmiştir. $\mathrm{Bu}$ süreç içinde en önemli değişiklik 01/01/2017 yılında uygulamaya giren Otomatik Katılım Sistemi olmuştur. Böylelikle sisteme gönüllülük esasına göre katılımdan vazgeçilmiştir. 45 yaşının altındaki ülke vatandaşı olan devlet ya da özel sektördeki çalışanların sisteme girişi otomatik şekilde yürürlüğe girmiştir. Fakat hali hazırdaki var olan durum hem devlet sektöründe hem de özel sektörde arzu edilen düzeye ulaşamamıştır. Bu durum otomatik katılım sistemi ile ilgili yeni düzenlemeler ortaya konmasını mecburi kılmıştır. $\mathrm{Bu}$ düzenlemeler yapılmadan önce sistemle alakalı hangi hususların elden geçirilmesi gerektiği belirlenmelidir. Zira sisteme katılanların beklentileri ve istemedikleri durumları belirlemeden yapılacak değişiklikler yine sistemden istenilen durumu vermeyecektir.

Ülkelerin emeklilik sistemlerinde büyük düzeydeki farklılıklarla birlikte, emeklilik fonları ve sosyal güvenlik sistemlerinin önemli oranda üçayaklı bir sistem üzerine bina edildiği görülmektedir (Kara ve Yıldız, 2016: 25). İlk ayak, mecburi sosyal güvenlik emeklilik programı yani dağıtım temeline bağlı geleneksel devlet emeklilik düzeni uygulamasıdır. Sosyal güvenliğin, kamu otoritesince sağlandığı ve değişik yaş grupları arasında kazancın tekrar tahsisini sağlayan sistem, emekli kişilere yapılan ödemelerin şu anki çalışan kişilerden sağlanan katkılar ile karşılanması temeline göre finanse edilmektedir. İkinci ayak mesleki emeklilik gelirlerine bağlı olup genelde çalışma ilişkisi ya da belirli bir mesleğin yürütülmesine bağlı bir gruba hitap etmektedir. Üçüncü ayak ise özel emeklilik gelirlerine bağlı olmaktadır. Bireysel emeklilik programlarını da içine alan özel emeklilik programları tahsis sistemi, mesleki emeklilik sistemi ya da her ikisinin birden tamamlayıcısı olarak da kullanılabilmektedir. Buradaki maksat bireysel desteklerin değerlendirilerek sağlanan fonun bir emeklilik yararı şeklinde kişiye ödenmesidir

Bireysel emeklilik planlarının küresel çapta yaygınlaşması, bu planlarda farklı ihtiyaçlara hitap eden farklılığ meydana getirmiştir. Emeklilik sistemlerinin karmaşık ve devletten devlete farklılaşan sistemler olması emeklilik yatırım kararını aynı zamanda devletlerdeki kurumsal farklılıklara bağlı olarak değişen bir yapı durumuna getirmiştir (Frericks vd., 2007: 213). Küresel emeklilik düzenlerinin ve bu sistemlerde meydana gelen farklılıkların 1990'ların başından şimdiye 
kadar önemli seviyede değiş̧iklik gösterdiği ortadadır (Holzmann, 2013: 1). Ülkemizinde içinde yer aldığ ç̧ogu ülkede bireysel emeklilik uygulamaları, sosyal güvenlik sistemini tamamlayan bir nitelik ortaya koymaktadır. Fakat, çalışanların önemli bir kesimini emeklilik sistemi içine katmak ve istenilen düzeyde yüksek tamamlayıcı emeklilik seviyesine ulaşmak maksadıyla Avusturya, Şili ve benzeri bazı devletlerde kurulan bireysel emeklilik programları mecburi fonlama temeline bağlı olmaktadır (Antolin vd., 2012: 5). Türkiye'deki emeklilik fonları diğer OECD ülkeleri ile karşılaştırıldığında gayri safi milli hasılaya oranı çok düşük seviyelerde seyretmesi sebebiyle bireysel emeklilik mevzuunda Türkiye'de büyük bir potansiyel olduğu ifade edilebilir.

Ülkemizde hemen hemen bir milyon kadar bir nüfusa sahip olan öğretmenlerin otomatik katılım sisteminden çıkma nedenlerinin belirlenmesi ve bu alanda yeni düzenlemeler yapılması sistemden arzu edilen başarının elde edilmesine katkı sağlayacaktır. Sistemin ülkemizin ekonomisi için önemi göz önüne alındığında sistemden çıkan bireylerin ayrılık nedenlerinin tespit edilmesi için Sivas'ın Suşehri ilçesinde görevli bulunan 235 öğretmen üzerinde bir çalışma yürütülmüştür. Araştırma anketinin birinci bölümünde sisteme katılanların demografik özelliklerinin dağılımını tespit etmeye yönelik 6 adet soru vardır. İkinci bölümde ise katılımcıların Otomatik Katılım Sistemi ile alakalı bilgi seviyelerini ve görüşlerini ölçmeye yönelik 16 adet çoktan seçmeli soru bulunmaktadır. Üçüncü bölümde ise katılımcıların sistem hakkındaki tutum ve davranışlarını belirlemek maksadıyla5'li Likert tipinde hazırlanan 15 adet ifade yer almaktadır.

\section{Otomatik Katılım Sisteminin Mevcut Durumu}

Otomatik Katılım Sistemi (OKS); 01/01/2017 tarihinde yürürlüğe giren 4632 sayılı Bireysel Emeklilik Tasarruf ve Yatırım Sistemi Kanunu'nun otomatik katılıma ilişkin hükümleri çerçevesince, çalışanların OKS'ne dâhil edilmesidir (www.egm.org.tr). Özel sektördeki çalışanların prime esas gelirleri ile kamu sektörü çalışanlarının emeklilik keseneğine esas gelirlerinin \%3’ünün sisteme ödenmesi zorunludur. OKS, Türkiye Cumhuriyeti vatandaşı veya mavi kartı bulunan 45 yaşını henüz tamamlamamış, devlet sektöründe ya da özel sektörde bir işveren grubuna bağlı şekilde maaş mukabilinde çalışanları içine almaktadır.

\subsection{Devlet Katkısı}

Devlet desteği uygulamasının sisteme katılmasından önce kişilerin sisteme yaptığ 1 katkılar, belirli sınırlar içinde bireyin vergi matrahından azaltılarak vergi teşviki sağlanmaktaydı. $\mathrm{Bu}$ destekden faydalanabilmek için sisteme katılan, eşi ve küçük çocukları adına katkı payı ödeyen bireyin öncelikle gelir vergisi yükümlüsü olması gerekmekteydi (Aydın ve Kaplan, 2014: 111). Bu sebeple gelir vergisi yükümlüsü olmayan bireyler vergi teşvikinden faydalanamıyordu. Devlet desteği uygulaması ile bireysel emeklilik sistemindeki daha çok kişinin teşvikten faydalanmasına imkân tanınmıştır.

Vergi teşviki uygulamasında bireysel emeklilik katılımcısı vergiden belli bir oranda indirim hakk1 sağlamakta ve bundan dolayı net ücretlerinde bir artış meydana gelmekteydi (Sezgin ve Yıldırım, 2015: 132). Yeni sistemde ise her katılımcı birey için \%25 devlet desteği ödenmektedir. Devlet desteği, katılımcı temelinde hesaplanan ve katılımc1 ismine ödenen katk1 payının \%25'i tutarında bir desteğin devletçe, sisteme katılanların hesaplarına ödenmesidir.

Devletin \%25 prim katkıs1, milli tasarruf düzeyini gelişmiş devletler seviyesine çekebilmek, yatırımcının kazanamama riskini en düşük seviyeye çekmek ve net \% 25 kazanç imkânı sağlama maksadı taşımaktadır. Devlet desteği, 01/01/2013 tarihinden sonra yapılacak olan katk1 payları için ödenmeye başlanmış idi (Büyükkara ve Balc1, 2014: 8). Her ne kadar aylık ödenen destek düzeyinin \%25'i kadar devlet desteğini hak etmiş olsa da bu tutar kişinin BES hesabına yatırılmadan ayrı bir fonda takip edilir. Burada dikkate alınan süre ve oranlar ise;

- En az 3 y1 BES üyesi olunması durumunda devlet desteğinin \%15'ine,

- En az 6 y1 BES üyesi olunması durumunda devlet desteğinin \%35'ine, 
- 10 y1l BES üyesi olunması durumunda devlet desteğinin \%60'ına,

- Emekli olmak, vefat etmek veya maluliyet durumunda devlet desteğinin \%100'ü hak edilmektedir.

Otomatik katılım sistemi ile birlikte iki ay süresince cayma hakk1 dönemi sonunda sistemdeki üyeliği süren katılımcı bireye 1.000 Türk Lirası devlet teşviği verilmektedir. Sistemde yer alan birey emeklilik hakkı süresi dolmasına ve birikimlerini toplu şekilde almayıp asgari 3 yıl maaşa bağlanmasını istemesi durumunda, bütün birikiminin \%5'i kadar ek devlet teşviki uygulanmaktadır (www.hsbc.com.tr, E.T 09.01.2020).

\subsection{Cayma Hakkı}

Otomatik Katılım Sistemi ile gönüllülük temelinde sisteme üye olma hali ortadan kalktığı için bazı katılımcılar sistemden ayrılmak istemektedir. İlk katkı payının emeklilik şirketinin hesabına yattığı günü takip eden ilk iş günü emeklilik planı, bireye posta veya elektronik posta aracılığıyla gönderilmektedir. Bu tebliğin sisteme katılan bireye ulaşmasından sonraki iki ay "BES cayma süresi" olarak ifade edilmektedir (www.sigortaladim.com, E.T. 15.01.2019). Sisteme katılanlar cayma süresi dâhilinde sistemden ayrılma hakkını, birikimleri üzerinde herhangi bir maddi kesintiye uğramadan kullanabilme hakkına sahiptir

Bireysel Emeklilik Sistemi'nde otomatik katılım yönetmeliğinde meydana gelen değişiklik ile sistemden ayrılma hakkını kullananlar için önceden 2 yıl olan mecburi geri dönüş süresi 3 yıla çıkarılmıştır. Hazine ve Maliye Bakanlığı, lüzum görmesi durumunda otomatik katılım süresini 5 y1la kadar uzatma yetkisine sahiptir (www.haberturk.com, E.T. 14.01.2019). Yeni sistemde farkli hallere göre sistemden çıkma durumunda kazanç üzerinden yapılacak kesinti tutarları şöyledir (Büyükkara ve Balc1, 2014: 8):

- 10 yıldan daha az katk1 payı ödeyerek sistemden çıkma durumunda, \%15

- 10 yıldan fazla katkı payı ödemesine rağmen 56 yaşını doldurmadan sistemden çıkma durumunda, \%10

- Emeklilik hakkını elde ederek sistemden çıkma durumunda, \%5

- Vefat, maluliyet gibi mecburi sebeplerden dolayı çıkma durumunda, \%5

\subsection{Otomatik Katılım Sistemi İstatistiki Bilgileri}

14 Şubat 2020 tarihi itibariyle OKS'de katılımcı sayısı 5.407 .394 birey olmuştur. Sisteme üye olan birey sayısı artmaktadır. Toplam katkı payı tutarı ise 6.613 milyon Türk Lirası olarak tespit edilmiştir.

Tablo 1: Otomatik Katılım Sistemi Katılımeı ve Fon Bilgileri

Katılımcıların Fon Tutarı

\begin{tabular}{lr}
\hline Faizli Fon Tutarı & 3.171,4 Milyon TL \\
\hline Faizsiz Fon Tutarı & $5.422,2$ Milyon TL \\
\hline Katılımcıların Sayısı & $\mathbf{5 . 4 0 7 . 3 9 4 ~ K i s ̧ i ~}$ \\
\hline Katkı Payı Tutarı & $6.613,4$ Milyon TL \\
\hline Sertifika Tutarı & 6.506 .972 Adet \\
\hline İşveren Sayısı & 214.944 \\
\hline
\end{tabular}

Kaynak:https://www.egm.org.tr, E.T.14.02.2020

Tablo 1'de ayrıca 14 Şubat 2020 tarihi itibariyle Otomatik Katılım Sistemi ile alakalı var olan katılımcı sayısının yanında katılımcıların faizli ve faizsiz fon tutarları bilgisi yer almaktadır. 
Tablo 2: Otomatik Katılım Sisteminde Kamu Sektöründe Cayma Oranı

\begin{tabular}{lcc} 
& Kamu & Oran \\
\hline Üyeliği Devan Edenler & 1.434 .404 & $36,60 \%$ \\
\hline Cayma Hakkını Kullananlar & 2.484 .713 & $63,40 \%$ \\
\hline
\end{tabular}

Kaynak: https://www.egm.org.tr, E.T. 14.02.20120

Tablo 2'ye göre 14 Şubat 2020 tarihi itibariyle devlet sektöründeki katılımcıların OKS'den ayrilma oranı $\% 63,4$ 'dür.

\section{Bireysel Emeklilik Sistemi Fonlarına Ait Muhasebe İșlemleri}

BES otomatik katılım uygulamasında yapılan her ișlemin muhasebe kayıtlarında gösterilmesi gerekir. Katılımcı gelirinden yapılan BES kesintisinin ișyeri ve sigorta șirketince yapılan muhasebe kayıtları, kesilen katkı payı ile fon alım/satım durumu, $\% 25$ düzeyinde devlet desteğinin yansitılması, devlet desteğinin hesaba yansıtılması, sistemden çıkma halinde katkı payının bireye ödenmesine kadar ki tüm süreçte oluşturulan muhasebe kayıtlarıyla ilgili örnekler başlıklar şeklinde ortaya konmuştur.

\subsection{BES Kesintisinin Ücret Tahakkuk Kaydında Gösterilmesi}

Sistemin uygulanmasında katkı payı tutarının hesaplanırken bireyin brüt geliri üzerinden $\% 3$ oranında BES kesintisi uygulanmaktadır.

Örnek: Mehmet Yılan, Bahar mağazasında pazarlama departmanında aylık brüt asgari ücret ile çalışan zorunlu bireysel emeklilik sistemine tabi evli olmayan bir çalışandır. Çalışana ait Nisan ayı ücret tahakkuk işlemi ile muhasebe kayıtları şöyle yapılacaktır.

ABAÜ

SGK İşçi Payı

SGK İşçi İşşizlik Pay1

Gelir Vergisi Matrahı

Gelir Vergisi

Damga Vergisi

BES

Net Ücret

İşv. SGK Payı

İşveren İşsizlik Payı
$: 2558.40$

$: 2558.40 * 0.14=358.18$

$: 2558.40 * 0.01=25.58$

$: 2558.40-358.18-25.58=2174.64$

$: 2174.64 * 0,15=326.20$

$: 2558.40 * 0.0759=19.42$

$: 2558.40 * 0.03=76$

: $2558.40+191.88-358.18-25.58-326.20-19.42-76=1944,90$

: $2558.40 * 15,5=396,55$

: $2558.40 * 0.02=51,17$

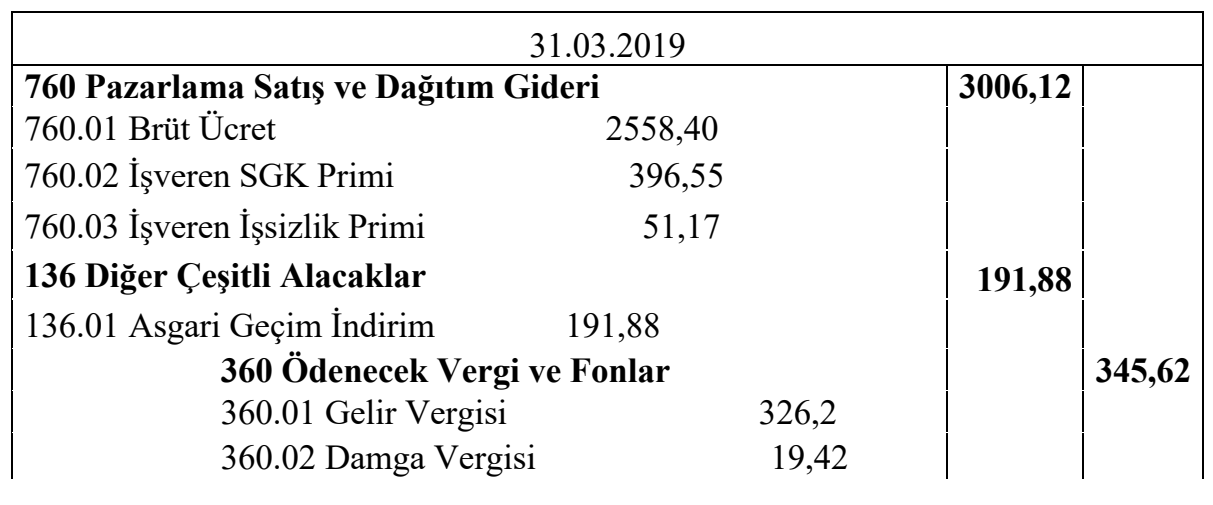

www.turkishstudies.net/economy 


\begin{tabular}{|lr|r|r|}
\hline \multicolumn{2}{|l|}{ 361 Ödenecek Sos. Güv. Kesintileri } & & $\mathbf{8 3 1 , 4 8}$ \\
361.01 İşçi SGK Primi & 358,18 & & \\
361.02 İşci İşsizlik Primi & 25,58 & & \\
361.03 İşveren SGK Primi & 396,55 & & \\
361.04 İşveren İşsizlik Primi & 51,17 & & \\
335 Personele Borçlar & & $\mathbf{1 9 4 4 , 9}$ \\
335.01 Personel Ücretleri & 1753,02 & & \\
335.02 Asgari Geçim İndirimi & 191,88 & & \\
369 Ödenecek Diğer Yükümlülükler & \\
\hline
\end{tabular}

Örnek: Evli, eşi çalışmayan 2 çocuklu 6066,48 lira brüt ücretle çalışan zorunlu bireysel emeklilik sistemine dahil bir çalışanın net ücretinin hesaplanıp muhasebe kaydının yapılması:

Brüt Ücret

SGK İşçi Payı

: 6066,48

SGK İşçi İşşizlik Payı

$: 6066,48 * 0,14=849,31$

Gelir Vergisi Matrahı

Gelir Vergisi

Damga Vergisi

BES

Net Ücret

İşveren SGK Payı

İşveren İşsizlik Payı
$: 6066,48-849,31-60,66=5156,51$

$: 5156,51 * 0,15=773,48$

: $6066,48 * 0,0759=46,04$

$: 6066,48 * 0,03=181,99$

: 6066,48+664,46-849,31-60,66-773,48-46,04-181,99=4819,46

: $6066,48 * 20,5=1243,63$

: $6066,48 * 0,02=121,33$

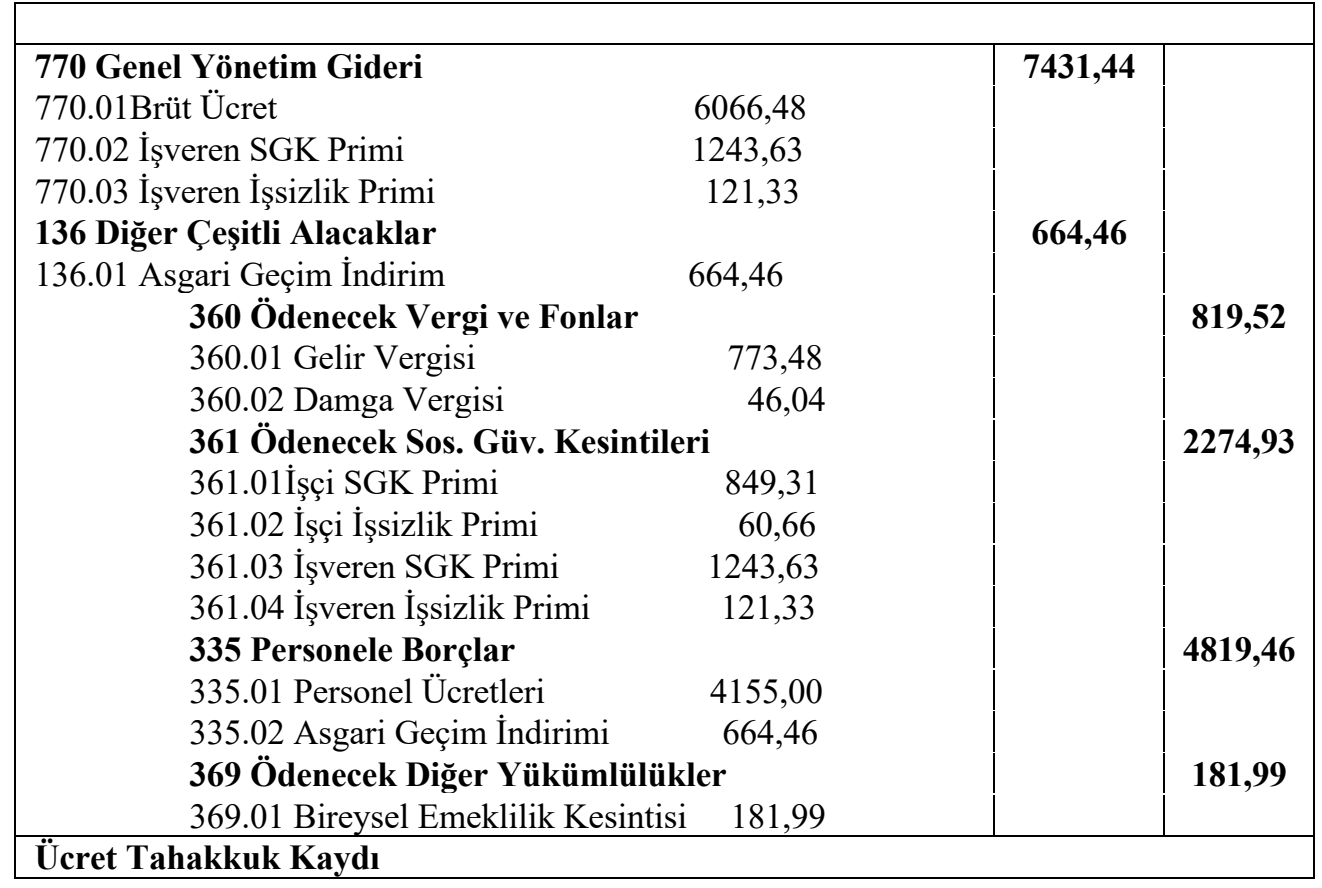

\subsection{Katkı Payının İlgili Hesapta Gösterimi}

Katılımcının brüt ücreti üzerinden \%3 oranında kesilen katılım payı sözleşmede ifade edilen fonda değerlendirilerek izlenmektedir. Katılımcının banka hesaplarında izlenebileceği fon vaziyeti 327 Katılımcılar Geçici Hesabında izlenilmektedir. 
Örnek: Suşehri Mesleki ve Teknik Anadolu Lisesi'nde öğretmen olan Hasan CAN'ın brüt maaşı 5.270 TL'dir. Zorunlu bireysel emeklilik sistemi dâhilinde Halk Emeklilik ve Yaşam Anonim Şirketi'ne alt limit üzerinden aylık bazda ödemesi vardır. Adı geçen öğretmenin ödemesinin takibine ait muhasebe kaydı şu şekilde yapılacaktır.

BES Katılım Payı Kesintisi: $10.540 * 0,03=316,2 \mathrm{TL}$

\begin{tabular}{|c|c|c|c|}
\hline \multicolumn{4}{|c|}{31.03 .2019} \\
\hline $\begin{array}{l}\text { 102.01 Bankalar } \\
\text { 102.01.1 Hasan CAN } \quad 316,2\end{array}$ & & 316,2 & \\
\hline \multicolumn{2}{|c|}{ 327.06 Katılımcılar Geçici Hesabı } & & 316,2 \\
\hline 327.06.1 Hasan CAN & 316,2 & & \\
\hline
\end{tabular}

\subsection{Katkı Payı ile Fon Alımı}

Emeklilik yatırım fonlarının kuruluş ve denetim giderlerinin düşürülmesi için düzenlemeler yapılmıştır. Bu bağlamda fonların hesap ve işlemlerinin bağımsız dış kontrol yükümlüğü senede 4 'ten 1'e indirilmiş, fon iç tüzügünün notere tasdik ettirilmesi mecburiyeti iptal edilmiştir. Son olarak yatırım fonlarının direkt olarak değerli madenlere yatırım yapabilmesine, kira sertifikalarına ve fon sepeti gibi araçlara yatırım olanağ 1 verilerek ürün çeşitlendirmesi de artırılmıştır (Yazıcı, 2015: 82). Katılımcının her ay düzenli olarak brüt geliri üzerinden hesaplanarak kesilen katılım payı ile faizli ya da faizsiz fonlara yatırım yapılabilir. Fonun alım/satım sürecinde icra edilen faaliyetler muhasebeleştirmeye tabidir.

Örnek: Mevlana Mesleki ve Teknik Anadolu Lisesi'nde görevli olan Adil BEYAZ isimli öğretmenin aylık brüt ücreti 5.210 TL'dir. Bu ücrete bağlı olarak \%3 oranında aylık katılım payı kesilmekte ve bu tutar ile pay senedi fonu alınmaktadır. Nisan ayındaki katılım payı ile fon alım işleminin muhasebeleştirilmesi:

BES katılım payı tutarı: $5.210 * 0,03=156,3$

\begin{tabular}{|c|c|c|}
\hline \multicolumn{3}{|c|}{31.03 .2019} \\
\hline $\begin{array}{c}\text { 327.06 Katılımcılar Geçici Hesabı } 156,3 \\
\text { 327.06.1 Adil BEYAZ } 156,3\end{array}$ \\
327.05 Alım Emirleri & & \\
\hline Fon satın alma emri & & $\mathbf{1 5 6 , 3}$ \\
\hline
\end{tabular}

\subsection{Katkı Payı ile Alınan Fonun Satılması}

Katılımcılar katılma hisseleriyle satın aldıkları fonlarda değişiklik isteyebilir veya satabilirler. Fon satış işlemlerinden bazı kesşntiler de yapılabilmektedir.

Örnek: Katılımcı Mehmet KARA katılım paylarını ile aldığı hisse senedi fonlarını satmak istiyor. Hesabında 1.000 TL'lik pay senedi fonu vardır. Fon satma işlemi muhase kaydı:

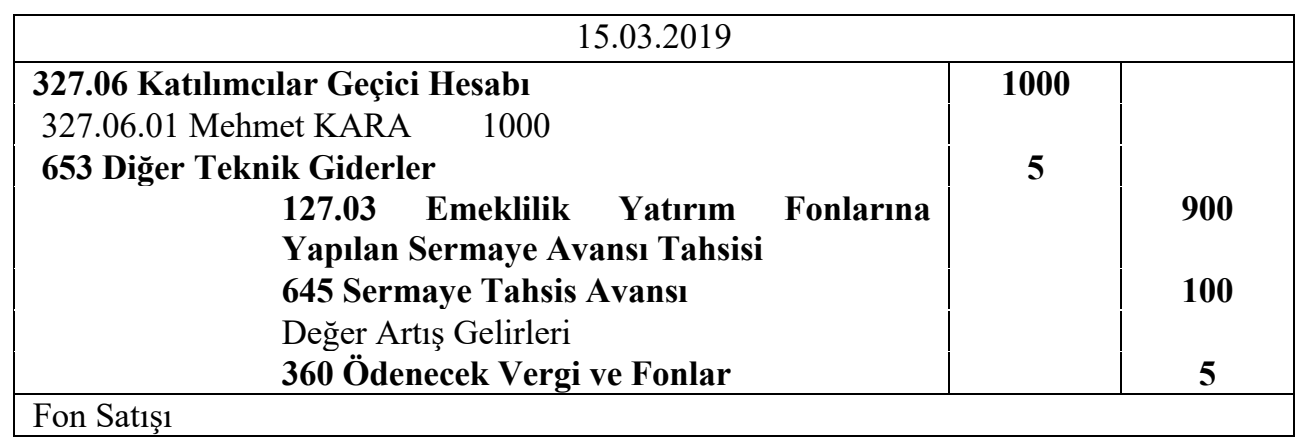




\subsection{Devlet Katkısının Emeklilik Şirketine Bildirilerek Hesaba Aktarılması}

01/01/2017 tarihi itibariyle uygulanmaya başlanan yeni sistem ile bireylerin katılım paylarının \%25'i nispetinde devlet katkısı sağlanmaktadır. Katılımcının aylık olarak hesabından yapılan kesintiyle beraber devlet desteği öncelikle şirkete tebliğ edilmekte daha sonra ise şirket hesaplarına yansitılmaktadir.

Örnek: Katılımcı Ali ASLAN'nın brüt ücreti üzerinden ay bazında 400 TL'lik katılım payı kesintisi yapılmaktadır. Katılımcının hak ettiği devlet desteğinin şirkete haber verilerek, hesabına yansitılması olayına ait muhasebe kaydı:

\begin{tabular}{|c|c|c|}
\hline \multicolumn{3}{|l|}{15.03 .2019} \\
\hline $\begin{array}{l}\text { 127.01.2 Diğer Ticari Alacaklar } \\
\text { 327.06 Katılımcılar Geçici Hesabı } \\
\text { 327.06.02 Devlet Desteği } 100 \\
\text { Sirkete haber verme }\end{array}$ & 100 & 100 \\
\hline \multicolumn{3}{|l|}{ 17.03.2019 } \\
\hline $\begin{array}{l}\text { 102.01 Bankalar } \\
\text { 102.01.2 Devlet Katkıs1 } \quad 100 \\
\quad \mathbf{1 2 7 . 0 1 . 2} \text { Diğer Ticari Alacaklar } \\
\text { Katk1 Payının Şirkete Aktarılması }\end{array}$ & 100 & 100 \\
\hline
\end{tabular}

\subsection{Fonda Toplanan Katılımcı Payının İlgili Kișiye Ödenmesi}

Katılımcı, fonda biriken payının tamamını alabileceği gibi emeklilik hakkını elde etme yaşına ulaştığı durumda emeklilik aylığı olarak da birikim payını alma hakkına sahiptir.

Örnek: Katılımcı Mahmut KAÇAR sistemdeki biriken toplam 102.514 TL'sini toplu şekilde almak arzusunu emeklilik şirketine haber vermiş ve bildirdiği hesaba birikimi aktarılmıştır.

\begin{tabular}{|c|c|c|}
\hline \multicolumn{3}{|l|}{15.03 .2019} \\
\hline 327.06 Katılımcılar Geçici Hesabı & 102.514 & \\
\hline $\begin{array}{l}\text { 327.06.1 Mahmut Kaçar } 102.514 \\
\text { 102.01 Bankalar } \\
\text { 102.01.1 Mahmut Kaçar Katılımcı 102.514 }\end{array}$ & & 102.514 \\
\hline
\end{tabular}

Katılımcı emeklilik kesintisi toplamlarını toplu şekilde almak yerine aylık düzenli şekilde emekli maaşı almak arzu ederse yine aynı kayıt yapılarak her ay tekrarlanacaktır.

Bireysel emeklilik sisteminde katılımcıların dikkat edecekleri önemli bir husus da sistemde yapılan kesinti tutarlarıdır. Katılımcı miktarı ve fon büyüklüğü artışına rağmen kesintilerin yüksekliği sisteme katılımı negatif yönde etkileyen esas meselelerden biri olarak görülmektedir (Peker, 2016: 101). BES mevzuatında yapılan düzenlemelerle tüm kesinti kalemlerinde azalma yönünde ciddi değişiklikler yapılmıştır.

\section{3. Öğretmenlerin Sisteme Bakışına Yönelik Bir Analiz}

Ülkemiz genelinde hemen hemen bir milyon civarında bir nüfusu teşkil eden öğretmenlerin sisteme yönelik algılarının belirlenerek aksayan yönlerinin tespit edilmesi, yapılacak yeni düzenlemeler için yardımcı olacaktır.

\subsection{Araştırmanın Konusu}

01/01/2017 tarihi itibariyle bireysel emeklilik sisteminde otomatik katılım uygulamas1 başlamıştır. Uygulamanın başlarından bu yana sistemden cayma hakkını kullanarak ayrılan sayısı ciddi boyutlara ulaşmıştır. 30.01.2020 tarihi itibariyle Emeklilik Gözetim sistemi verilerine göre 
cayma oranı kamu sektöründe \% 63 seviyesindedir. (https://www.egm.org.tr, E.T.13.02.2020). Bu oranın milli eğitim camiasında bulunan katılımcılar arasında da benzerlik olup olmadığını belirlemek, sistemden ayrılma hakkını kullanarak çıkan bireylerin bu hakkını kullanma nedenlerini tespit etmek araştırmanın konusunu teşkil etmektedir.

\subsection{Araştırmanın Önemi}

Bireysel emeklilik sistemi diğer ismiyle otomatik katılım sistemi gerek fon büyüklüğü gerek katılımcı sayısı bakımından büyük önem arz eden bir uygulama olduğu bilinmektedir. Buna rağmen katılımcı sayısında meydana gelen azalma istenilen fon hacminden uzaklaşmaya neden olmuştur. Katılıcıların sistemden çıkma nedenlerinin tespit edilerek, bu nedenler üzerinde yapılabilecek yeni değişiklikler ile katılımcıların sistemden çıkması engellenerek hedeflenen fon hacmine ulaşmak mümkün olacaktır.

\subsection{Araştırmanın Amacı}

Bireylerin gelecekle alakalı endişeleri, iş hayarında yapacakları küçük tutarlardaki tasarruflar ile emeklilikte ikinci bir maaş alma imkanı, emniyetli ve şeffaf bir ortamda yatırım yapabilme firsatı ve devletçe sağlanan destek ile birlikte Bireysel Emeklilik Sistemi hızlı şekilde yayılmıştır. 27/10/2003'de fiilen üye kaydetmeye başlayarak yaşamımıza dâhil olan BES yıllar ilerledikçe bazı yasal düzenlemelere tabi olmuştur. 01/01/2017'den itibaren ise OKS aşamalı olarak uygulanmaya başlanmıştır (https://www.egm.org.tr, E.T. 13.02.2020). Bu tarih ile beraber ilgili kriterleri sağlayanlar sisteme katılmak durumunda kalmıştır. Fakat bu değişiklik yatırımcılar nezdinde arzu edilen geri dönüşü ortaya koymamıştır. Sistemden yüksek oranda çıkmalar olmuştur. $\mathrm{Bu}$ ayrılıklar hususunda yetkili kişi, kurum ve kuruluşlar yeni metotlar aramakta, çıkan bireylerin tekrardan sisteme katılmasını sağlayacak çalışmalar yapmaktadır.

$\mathrm{Bu}$ vaziyet uygulamayla alakalı bazı sıkıntılar yaşandığını ortaya koymuştur. Bu noktada sisteme katılanların cayma nispeti ve cayma nedenlerini tespit etmek maksadıyla bu çalışma düşüncesi ortaya çıkmıştır. Hemen hemen bir milyon kadar üyesi bulunan öğretmen topluluğunda cayma sebeplerini belirleyebilmek adına en uygun yöntemin anket olduğu düşünülmüştür.

\subsection{Araştırmanın Örneklemi}

Araştırmanın örneklemi, olasılığa dayalı olmayan örneklem metotlarından amaçsal örneklem yöntemi kullanılarak tespit edilmiştir. Eğitim camiasında bulunan hemen hemen bir milyon birey üzerinde bir araştırma yapmak çok büyük yük gerektirmesi sebebiyle ana kütleyi temsil edebilecek özelliklerde bir örneklem kitlesi üzerinde anket yapılması fikri ortaya çıkmıştır. $\mathrm{Bu}$ bağlamda araştırmanın örneklemini, Sivas ili Suşehri ilçesinde vazifeli olan toplam 235 öğretmen oluşturmaktadır (https://susehri.meb.gov.tr, Erişim Tarihi 20.09.2018). İlçede görev yapan öğretmen mevcudu 312'dir ve bu sayının 77'si ücretli statğde çalışmaktadır. Ücretli çalışan öğretmen kitlesi OKS'ye katılmadıklarından dolayı anket uygulamasına dahil edilmemiş ve geriye kalan 235 öğretmenin tamamına anket uygulaması yapılmıştır.

\subsection{Veri Toplama Aracı}

Araştırmada kullanılan veri toplama aracı 3 ana bölümden oluşmaktadır. Birinci bölümde katılımcıların demografik özelliklerinin dağılımını tespit etmeye yönelik 6 adet soru vardır. İkinci bölümde ise katılımcıların OKS ile alakalı bilgi seviyelerini ve düşüncelerini ölçmeye yönelik 16 adet çoktan seçmeli soru bulunmaktadır. Üçüncü bölümde katılımcıların OKS'ye yönelik tutum ve davranışlarını belirlemek maksadıyla 5'li Likert tipinde hazırlanan 15 adet ifade yer almaktadır.

\subsection{Araştırma Verilerinin Toplanması}

Araştırmanın veri toplama aracı, Sivas ilinin Suşehri kazasında vazife yapan kadrolu ve sözleşmeli toplam 235 öğretmene 2018-2019 Eğitim Öğretim yılı birinci döneminde yüz yüze 
anket metoduyla araştırma yapan tarafından gerçekleştirilmiştir. Uygulama neticesinde toplanan veriler SPSS 22.0 paket programına aktarılarak araştırmanın veri seti ortaya konmuştur.

\subsection{Kullanılan İstatistiksel Yöntemler}

İlk önce katılımcıların demografik durumlarına göre dağılımı frekans tablosu teşkil edilmiştir. Katılımcıların OKS ile ilgili bilgi seviyeleri ve fikirleri ise çapraz tablo aracıllğıyla ve ki-kare bağımsızlık testi kullanılarak değerlendirilmiştir. Farklı kategorilere ayrılmış iki olay arasındaki ilişkinin analizi bağımsızlık testiyle yapılmaktadır. Bu olaylara ait gözlenen frekansları gösteren iki yönlü tablolara kontenjan tablosu ya da çapraz tablo denilmektedir (Kartal 2006: 121). Bir çapraz tablo " $r$ " tane satır ve " $\mathrm{k}$ " tane sütundan oluşup " $\mathrm{r}$ x k" tipindedir. Çapraz tabloda görülen frekans dağılımlarındaki farklılığın anlamlılığı ki-kare bağımsızlık testi ile test edilir. $\mathrm{Bu}$ testte sıfır hipotezi "bu iki olay birbirinden bağımsızdır, birbirini etkilememektedir", alternatif hipotez ise "olaylar birbirine bağımlıdır, birbirini etkilemektedir" şeklinde kurulur. (Karagöz 2016: 665). Araştırmada kullanılan istatistiksel tekniklerin uygulanmasında IBM SPSS 22.0 paket programından faydalanıldı.

Yapılan Cronbach's Alpha güvenilirlik analizi sonucunda iç tutarlılık katsayısı 0,906 olarak bulunmuştur. $\mathrm{Bu}$ sonuç anketin güvenilirliğinin yüksek derecede güvenilir düzeyinde olduğunu göstermektedir (Karagöz, 2016, 420).

\subsection{Araştırmanın Hipotezleri}

Sivas ilinin Suşehri ilçesinde görev yapan kadrolu ve sözleşmeli toplam 235 öğretmene 2018-2019 Eğitim Öğretim y1lı güz yarıyılında yüz yüze anket yöntemi araştırmay1 yapan tarafından uygulanarak katılımcıların düşünceleri tam olarak ortaya konmuştur.

\section{Hipotezler;}

H1: OKS üyelikleri, katılımcıların yaşları bakımından anlamlı bir farklılık göstermektedir.

H2: OKS üyelikleri, katılımcı cinsiyetleri açısından anlamlı bir farklılık göstermektedir.

H3: OKS üyelikleri, katılımcıların medeni durumları yönünden anlamlı bir farklılık göstermektedir.

H4: OKS üyelikleri, katılımcıların sistem hakkındaki bilgilerine göre anlamlı bir farklılık göstermektedir.

H5: OKS üyelikleri, emeklilik için 56 yaşın uygun olması durumuna göre anlamlı bir farkl111k göstermektedir.

H6: OKS üyelikleri, katılımcıların faydasına olduğu fikrine göre anlamlı bir farklılık göstermektedir.

H7: OKS üyelikleri, katılımcıların sistemi yatırım aracı görmesi durumuna göre anlamlı bir farkl1l1k göstermektedir.

H8: OKS üyelikleri, sistemin otomatik olmasına göre anlamlı bir farklılık göstermektedir.

H9: OKS üyelikleri, katılımcıların birikimlerini toplu alabilmesi tercihine göre anlamlı bir farkl111k göstermektedir.

H10: OKS üyelikleri, devlet desteğine verilen öneme göre anlamlı bir farklılık göstermektedir.

H11: OKS üyelikleri, devlet desteğinin sisteme katılım etkisine göre anlamlı bir farklılık göstermektedir. 


\subsection{Araştırmanın Sinırlılıkları}

Araştırma ile ilgili kısıtlar şöyledir;

- Sağlanan veriler yalnızca kullanılan veri toplama aracına verilen cevaplardan ibarettir.

- Araştırma grubu yalnızca Sivas vilayeti Suşehri kazası ile sınırlıdır.

- Araştırma grubu milli eğitim bakanlığında görev yapan; kadrolu ve sözleşmeli öğretmenleri içermektedir.

\subsection{Araştırmanın Bulguları}

Araştırma bulguları temelde iki alt başlık halinde değerlendirilecektir.

\subsubsection{Demografik ve Genel DüşünceyeAit Bulgular}

Ankette bulunan her bir soru için verilen cevaplar tablolar şeklinde aşağıdaki gibidir;

\begin{tabular}{lcr}
\multicolumn{3}{c}{ Tablo 3: Katılımciların Cinsiyet Dağ 1 lımı } \\
\hline Cinsiyet & Frekans & Yüzde (\%) \\
\hline Erkek & 137 & 58,3 \\
Kadın & 98 & 41,7 \\
\hline Toplam & 235 & 100 \\
\hline
\end{tabular}

Araştırmaya katılan 235 kişinin yüzde 58,3'ünü erkek, yüzde 41,7'si ise kadındır.

Tablo 4: Katılımcıların Yaş Dağılımı

\begin{tabular}{lcr}
\hline Yaş Dağılımı & Frekans & Yüzde (\%) \\
\hline $18-25$ & 13 & 5,5 \\
$26-33$ & 124 & 52,8 \\
$34-41$ & 59 & 25,1 \\
$42-49$ & 22 & 9,4 \\
$50-57$ & 15 & 6,4 \\
58 ve üzeri & 2 & 0,8 \\
\hline \multicolumn{1}{c}{ Toplam } & 225 & 100 \\
\hline
\end{tabular}

Katılımcıların yaş grupları analiz edildiğinde en fazla katılımcı grubu 26-33 yaş arasında oldukları görülmektedir. $\mathrm{Bu}$ grubun toplam katılımc1 içindeki oranı \%52,8'dir. Katılımcılar içindeki 10 kişi yaşını belirtmediği için 225 katılımcının görüşü değerlendirmeye alınmıştır.

Tablo 5: Katılımcıların Medeni Durum Dağılımı

\begin{tabular}{lcr} 
Medeni Durum & Frekans & Yüzde (\%) \\
\hline Bekar & 68 & 28,9 \\
Evli & 167 & 71,1 \\
\hline Toplam & 235 & 100 \\
\hline
\end{tabular}

Araştırmaya katılanların \%71,1'i evlidir. Bekâr öğretmenlerin oranı ise \% 28,9'dur.

Tablo 6: Katılımcıların Öğrenim Durumları

\begin{tabular}{lcr}
\hline Öğrenim Durumu & Frekans & Yüzde (\%) \\
\hline Lisans & 209 & 88,9 \\
Yüksek lisans & 26 & 11,1 \\
Doktora & 0 & 0 \\
\hline Toplam & 235 & 100 \\
\hline
\end{tabular}


Araştırmaya katılanların \% 88,9'luk kısmı lisans mezunu ve \%11,1'lik katılımcı kesimi yüksek lisans yapmıştır. Doktora yapmış öğretmen araştırma zamanında ilçede yoktur.

Tablo 7: Katılımc1ların OKS ile İlgili Bilgi Durumları

\begin{tabular}{lcr}
\hline $\begin{array}{l}\text { Otomatik katılım sistemi } \\
\text { hakkında bilginiz var mı? }\end{array}$ & Frekans & Yüzde (\%) \\
\hline Evet & 199 & 84,7 \\
Hayır & 36 & 15,3 \\
\hline Toplam & 235 & 100 \\
\hline
\end{tabular}

Araştırma konusu ankete cevap veren katılımcilardan \% 84,7'si sistem hakkında genel düzeyde bilgi sahibi olduğunu ifade etmiştir.

Tablo 8: Katılımcıların Bilgi Kaynakları

\begin{tabular}{lcc}
\hline $\begin{array}{c}\text { Otomatik katılım sistemi hakkında } \\
\text { nereden bilgi edindiniz? }\end{array}$ & Frekans & $\begin{array}{r}\text { Yüzde } \\
\mathbf{( \% )}\end{array}$ \\
\hline İnternet & 105 & 44,7 \\
Görsel medya & 24 & 10,2 \\
Broşür & 2 & 0,9 \\
Arkadaş & 25 & 10,6 \\
Banka & 46 & 19,6 \\
Sigorta şirketleri & 3 & 1,3 \\
Diğer & 5 & 2,1 \\
Bilgim yok & 25 & 10,6 \\
\hline Toplam & 235 & 100 \\
\hline
\end{tabular}

Bilgi kaynağ ${ }_{1}$ olarak internet ortamını tercih edenlerin oranı $\% 44,7$ ile yarıya yakın bir oranı teşkil etmektedir. En yüksek ikinci kaynak ise \% 19,6 ile bankalardır.

Tablo 9: Katılımcıların Sisteme Dahil Olma Durumları

\begin{tabular}{lcc}
\hline Otomatik katılım sistemine dâhil misiniz? & Frekans & $\begin{array}{r}\text { Yüzde } \\
\mathbf{( \% )}\end{array}$ \\
\hline Evet & 68 & 28,9 \\
Hayır & 167 & 71,1 \\
\hline Toplam & 235 & 100
\end{tabular}

Ülke genelinde 14 Şubat 2020 itibariyle sistemden ayrılanların oranı \% 63 iken Araştırmanın yapıldığ 1 Suşehri ilçesinde bu oran \%71,1 olarak belirlenmiştir. Bu durum örneklemin ana kütleyi temsil etme durumunda olduğunu göstermektedir.

Tablo 10: Katılımciların Sistemden Ayrilma Sebepleri

\begin{tabular}{lcr}
\hline Otomatik katılım sisteminden ayrılma sebebiniz nedir? & Frekans & Yüzde (\%) \\
\hline Devlet desteğinin faiz olduğunu düşündüğüm için & 47 & 28,1 \\
Gereksiz buluyorum & 41 & 24,6 \\
Otomatik katılımı beğenmedim & 32 & 19,2 \\
Borcum var & 10 & 6,0 \\
Bireysel emeklilik sigortası olmadan da tasarruf yapıyorum & 15 & 9,0 \\
Uygulamanın yanlış olduğunu düşünüyorum & 3 & 1,8 \\
Gelirim yetersiz & 4 & 2,4 \\
Sistem hakkında yeterli düzeyde bilgi sahibi değilim & 5 & 3,0 \\
Birikimlerimi farklı alanlarda değerlendiriyorum & 10 & 6,0 \\
\hline
\end{tabular}




\begin{tabular}{lll}
\hline Toplam & 167 & 100 \\
\hline
\end{tabular}

Tablo 10'a göre sistemden çıkanların \% 28,1'lik kısmı devlet desteğini faiz olarak görmektedir. Sistemin verim sağlayabilmek için öncelikle katılımcıların aklında ki faiz ile alakalı negatif fikirler düzeltilmelidir. Araştırmada sistemi gerekli bulmayanların oranı \% 24,6 ile ikinci sırada bulunurken en yüksek orana sahip üçüncü oran ise \% 19,2'lik katılımcı kesimi ile sistemin otomatik olmasını beğenmeyen katılımcılar yer almaktadır. Katılımcılar bu hali bir dayatma şeklinde algılamaktadırlar. Sisteme katılımdan sonra iki ay içinde sistemden ayrılma durumunun olması bu oranın daha da yüksek çıkmasını engellemiş görünmektedir. \% 6'lık bir katılımcı ise farklı alanlarda yatırım yaptığını belirtmiştir.

Tablo 11: Sistemin Katılımcılar İçin Anlamı

\begin{tabular}{lcc}
\hline Otomatik katılım sistemi size ne ifade ediyor? & Frekans & Yüzde (\%) \\
\hline Tasarruf vasıtası olabilir & 58 & 24,7 \\
Emekliliğe maddi açıdan destek sağlar & 38 & 16,2 \\
Yanlış bir yatırım çeşidi & 37 & 15,7 \\
Geleceğin güvencesi olarak ifade edebiliriz & 14 & 6,0 \\
Kendi başıma tasarruf yapamadığım için gereklidir & 8 & 3,4 \\
Otomatik katılımlı olması kötü bir izlenim veriyor & 59 & 25,1 \\
Diğer & 21 & 8,9 \\
\hline Toplam & 235 & 100 \\
\hline
\end{tabular}

Tablo 11 analizinde katılımcı bireyler arasında OKS'nin yatırım aracından ziyade bir tasarruf aracı olduğu kanaatinde olanların oranı da \%24,7 ile her dört kişiden birini teşkil etmektedir. \%15,7'lik katılımcı kesimi ise bireysel emekliliğin hatalı bir yatırım olduğunu belirtmiştir. Yatırım denildiği zaman ilk olarak akla gelen araç altındır. Oysa sistem hakkında bireyler internet aracılığıyla değil de yetkililerce bilgilendirilmiş olsa otomatik katılım sisteminde katkı paylarının altın aracına endekslenebileceğini öğrenecek böylece de sistemden çıkma oranında dikkate değer bir azalma yaşanacaktır. İkinci emeklilik geliri faydasından yola çıkarak katılımcıların geleceğini güvence altına aldığını düşünenlerin oranı $\% 6$ ile en az orana sahip ikinci değer olarak görülmektedir. \%16,2 oranında katılımcı kesimi emeklilik durumunda maddi bir destek elde edeceği görüşünde olmasına rağmen geleceğini güvenceye aldığını düşünmemektedir. OKS sizin için ne ifade ediyor sorusuna \%25,1'lik bir kesim otomatik katılımı kötü bir izlenim veriyor cevabını işaretlemiştir. Katılımcılar kendi izinleri dışında sisteme katılmalarından rahatsızlık duymaktadırlar.

Tablo 12: Sistemde Kalma Süresi

\begin{tabular}{lcc}
\hline $\begin{array}{l}\text { Sistemde kaç yıl süre ile kayıtlı } \\
\text { kalabilirsiniz? }\end{array}$ & Frekans & Yüzde (\%) \\
\hline 3 Y11 & 12 & 17,6 \\
5 Y11 & 1 & 1,5 \\
10 Y11 & 25 & 36,8 \\
15 Y11 & 6 & 8,8 \\
20 Y1 & 2 & 2,9 \\
Emekli olana kadar & 22 & 32,4 \\
\hline Toplam & 68 & 100 \\
\hline
\end{tabular}

Sistemden çıkmayı düşünen bir katılımcı devlet desteğinin tamamından faydalanabilmesi için sistemde emekliliği beklemesi zorunludur. Emekliliği beklemeden sistemden ayrılmak isterse devlet desteğinden kesinti yapılmaktadır. Bu noktada katılımcı bireylere sistemde ne kadar süre 
kalacaksınız şeklinde yöneltilen soruya \% 36,8'lik bir kesim 10 yıl cevabını vermiştir. \% 32,4'lük katılımcı kesimi ise emekli olmayı bekleyeceklerini ifade etmiş̧lerdir.

Tablo 13: Devlet Katkısının Üyeliğe Etkisi

\begin{tabular}{lcc}
\hline $\begin{array}{l}\text { \%25 oranında devlet desteği ilave edilmesi sisteme } \\
\text { üye olmak için önemli bir etken midir? }\end{array}$ & $\begin{array}{r}\text { Yüzde } \\
\mathbf{( \% )}\end{array}$ \\
\hline Evet & 90 & 38,3 \\
Hayır & 86 & 36,6 \\
Kararsızım & 59 & 25,1 \\
\hline Toplam & 235 & 100 \\
\hline
\end{tabular}

Katılımcıların \%38,3'ü devlet katkısının üye olmak için bir etken olduğunu ifade ederken bu orana yakın bir katılımcı kesimi de devlet desteğinin üyelik için önemli olmadığını ifade etmektedir. \% 25'lik oranda verilen devlet desteği iyi bir oran olarak görülmesine rağmen fiyatlar genel seviyesi oranının yüksekliği sebebiyle katılımcılara yetersiz geldiği neticesine varılabilir.

\subsubsection{Hipotezlerin Sinanması}

$\mathrm{Bu}$ çalışmada daha önce de ifade edildiği üzere 11 tane hipotez geliştirilmiştir. $\mathrm{Bu}$ hipotezlerin katılımcılara ait belirtilen değişkenler açısından sınanmasına yönelik analizler aşağıda tablolar halinde sunulmuştur. Hipotezler, katılımcıların sisteme dâhil olup olmadıkları sorusuna verdikleri cevaplar (Evet veya Hayır) temelinde ifadelere ait bakışlarının ki-kare değeri hesaplanarak değerlendirilmiştir.

Tablo 14: Devlet Katkısına Verilen Önem ile Sisteme Üyelik Durumu İlişkisi

\begin{tabular}{|c|c|c|c|c|c|c|c|}
\hline \multirow[b]{2}{*}{$\begin{array}{l}\text { Otomatik katılım } \\
\text { sistemine dahil } \\
\text { misiniz? }\end{array}$} & \multicolumn{6}{|c|}{$\begin{array}{l}\text { Otomatik katılım sisteminde devlet desteği ne } \\
\text { kadar önemli? }\end{array}$} & \multirow{2}{*}{\begin{tabular}{|c|}
$\begin{array}{l}\text { Pearson } \\
\text { Chi-Square }\end{array}$ \\
\multicolumn{1}{c}{$\mathbf{X}^{2}$} \\
\end{tabular}} \\
\hline & 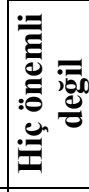 & 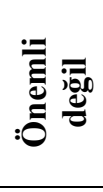 & 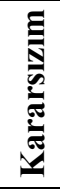 & : & 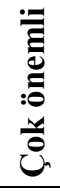 & $\stackrel{\bar{\pi}}{\theta}$ & \\
\hline Evet & 5 & 3 & 11 & 21 & 28 & 68 & \multirow{3}{*}{0,006} \\
\hline Hayır & 22 & 18 & 47 & 46 & 34 & 167 & \\
\hline Toplam & 27 & 21 & 58 & 67 & 62 & 235 & \\
\hline
\end{tabular}

Tablo 14'teki verilere bakıldığında katılımcı bireylerin \%54,9'u devlet katkısının önemli olduğunu belirtmiştir. Sistemde üyeliği bulunanlarda bu oran \%72'dir. Katılımcıların bu desteğe atfettikleri önem ile sisteme üyelikleri arasında anlamlı bir ilişkinin olduğu "ki kare" değerinden görülmektedir. Tablo14'deki "ki kare" değerine göre H10 hipotezi kabul edilmiştir.

Tablo 15: Sistemdeki Birikimleri Toplu Almak ile Sisteme Üyelik Durumu İlişkisi

\begin{tabular}{|c|c|c|c|c|c|c|c|}
\hline \multirow[b]{2}{*}{$\begin{array}{l}\text { Otomatik katılım } \\
\text { sistemine dahil } \\
\text { misiniz? }\end{array}$} & \multicolumn{6}{|c|}{$\begin{array}{l}\text { Otomatik katılım sisteminde } \\
\text { birikimleri toplu almak önemli } \\
\text { mi? }\end{array}$} & $\begin{array}{l}\text { Pearson } \\
\text { Chi-Square }\end{array}$ \\
\hline & 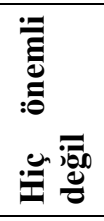 & 范 & 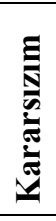 & ö & 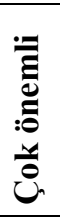 & $\stackrel{5}{0}$ & $\mathrm{X}^{2}$ \\
\hline Evet & 2 & 4 & 11 & 23 & 28 & 68 & \multirow{3}{*}{0,020} \\
\hline Hayır & 21 & 12 & 44 & 49 & 41 & 167 & \\
\hline Toplam & 23 & 16 & 55 & 72 & 69 & 235 & \\
\hline
\end{tabular}

Tablo 15'deki neticelere bakıldığında katılımcıların \% 60'1 birikimlerini toplu şekilde alabilmenin önemli olduğunu ifade etmiştir. Bu oran beklentinin ikinci emeklilik gelirinden ziyade 
toplu birikime sahip olmak olduğunu ortaya koymaktadır. Bu durum "ki kare" oranı ile de desteklenmektedir. Çünkü ülkemizde emeklilik hakkı elde etmiş kişiler için toplu birikim almaları konut veya araç alabilmeleri yönünden önemli bir tercihtir. Tablo 15'deki "ki kare" oranına göre H9 hipotezi de kabul edilmiştir.

Tablo 16: Sistemin Otomatik Olması ile Sisteme Üyelik Durumunun İlișkisi

\begin{tabular}{|c|c|c|c|c|c|c|c|}
\hline \multirow[b]{2}{*}{$\begin{array}{c}\text { Otomatik katılım sistemine } \\
\text { dahil misiniz? }\end{array}$} & \multicolumn{6}{|c|}{$\begin{array}{c}\text { Otomatik katılım sisteminde } \\
\text { sistemin zorunluluğu önemli mi? }\end{array}$} & \multirow{2}{*}{$\begin{array}{c}\begin{array}{c}\text { Pearson Chi- } \\
\text { Square }\end{array} \\
X^{2}\end{array}$} \\
\hline & 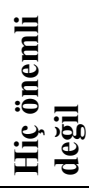 & 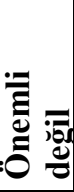 & 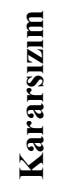 & 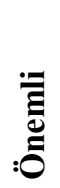 & 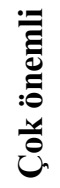 & $\stackrel{\bar{\sigma}}{\theta}$ & \\
\hline Evet & 19 & 7 & 20 & 5 & 17 & 68 & \multirow{3}{*}{0,454} \\
\hline Hayır & 45 & \begin{tabular}{|l|}
13 \\
\end{tabular} & 51 & 26 & 32 & 167 & \\
\hline Toplam & 64 & 20 & 71 & 31 & 49 & 235 & \\
\hline
\end{tabular}

Tablo 16'daki veriler değerlendirildiğinde tek başına sistemin otomatik olması ne kadar önemli olduğu ifadesine \% 34,1'lik kesim önemli ve çok önemli cevabını vermektedir. Fakat sistemden ayrilma sebebiniz sorusuna verilen cevapların \% 19,2'si sistemin otomatik olmas1 durumunu ifade etmiştir. $\mathrm{Bu}$ durum otomatik olmasından rahatsız olan bireylerin sadece yarıdan daha fazla kişinin sistemden çıktığını ortaya koymaktadır. Ki kare testi sonucu göz önüne alındığında sistemin otomatik olması ile sistemdeki üyeliğin devam etmesi arasında anlamlı bir ilişki yoktur. Tablo 16' da bulunan "ki kare" oranına göre $\mathbf{H 8}$ hipotezi reddedilmiştir.

Tablo 17: Sistemi Yatırım Aracı Görme Durumu ile Sisteme Üyelik Durumu İlişkisi

\begin{tabular}{|c|c|c|c|c|c|c|c|}
\hline \multirow[b]{2}{*}{$\begin{array}{l}\text { Otomatik katılım } \\
\text { sistemine dahil } \\
\text { misiniz? }\end{array}$} & \multicolumn{6}{|c|}{$\begin{array}{l}\text { Bireysel emeklilik sistemini iyi bir yatırım } \\
\text { aracı olarak görüyorum. }\end{array}$} & $\begin{array}{l}\text { Pearson } \\
\text { Chi-Square }\end{array}$ \\
\hline & 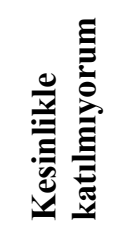 & 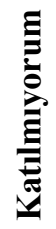 & 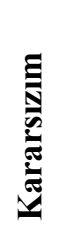 & 泀 & 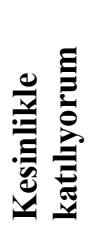 & 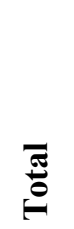 & $X^{2}$ \\
\hline Evet & 7 & 8 & 18 & 28 & 7 & 68 & \multirow{3}{*}{0,000} \\
\hline Hayır & 58 & 45 & 31 & 26 & 7 & 167 & \\
\hline Toplam & 65 & 53 & 49 & 54 & 14 & 235 & \\
\hline
\end{tabular}

Tablo 17'deki sonuçlara bakıldığında bireysel emekliliğin iyi bir yatırım olmadığı düşüncesinde olanların oranı \% 50,1'dir. Bu rakama kararsız olanları da ilave ettiğimizde oran \% 72'ye yükselmektedir. Sistemi yatırım aracı olarak görme değişkeniyle sisteme üye olma değiş̧keninin bağımlı değişken olduğunu "ki kare" değeri ortaya koymaktadır. Tablo 17'deki veriler dikkate alındığı zaman $\mathbf{H} 7$ hipotezi kabul edilmiştir.

Tablo 18: Düzenlemelerin Yatırımcılara Yararı Durumu ile Sisteme Üyelik Durumu İlişkisi

\begin{tabular}{|c|c|c|c|c|c|c|c|}
\hline \multirow[b]{2}{*}{$\begin{array}{l}\text { Otomatik katılım } \\
\text { sistemine dahil misiniz? }\end{array}$} & \multicolumn{6}{|c|}{$\begin{array}{l}\begin{array}{l}\text { Yeni düzenlemelerin yatırımcı faydasına } \\
\text { olduğunu düşünüyorum. }\end{array} \\
\end{array}$} & \multirow{2}{*}{$\begin{array}{c}\text { Pearson } \\
\text { Chi-Square } \\
\mathbf{X}^{\mathbf{2}}\end{array}$} \\
\hline & 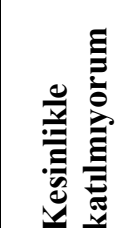 & 豆 & 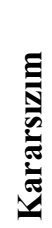 & 泀 & 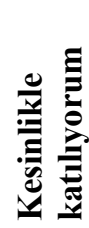 & 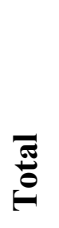 & \\
\hline Evet & 7 & 8 & 18 & 32 & 3 & 68 & 0,000 \\
\hline
\end{tabular}




\begin{tabular}{|l|l|l|l|l|l|l|l|}
\hline Hayır & 30 & 43 & 56 & 32 & 6 & 167 & \\
\cline { 1 - 6 } Toplam & 37 & 51 & 74 & 64 & 9 & 235 & \\
\hline
\end{tabular}

Tablo 18'deki sonuçlara göre \% 37,4'lük katılımcı kesimi 01/01/2017 tarihi itibariyle yeni yapılan düzenlemelerin katılımcı faydasına olmadığını ifade etmektedir. Bu noktada kararsızların oranı \% 31,5'dir. Bu iki oran birlikte değerlendirildiğinde \% 68,9 olmaktadır. Bu oran da sistemden ayrılma düzeyine paralellik göstermektedir. Yani katılımcılar rahatsız olma durumunu sistemden ayrılma eylemi ile göstererek tutarlı bir davranış ortaya koymuşlardır. H6 hipotezi kabul edilmiştir.

Tablo 19: Emeklilik İçin 56 Yaşın Uygun Olma Durumu ile Sisteme Üyelik Durumu İlişkisi

\begin{tabular}{|c|c|c|c|c|c|c|c|}
\hline \multirow[b]{2}{*}{$\begin{array}{l}\text { Otomatik katılım sistemine } \\
\text { dahil misiniz? }\end{array}$} & \multicolumn{6}{|c|}{$\begin{array}{l}\text { Emekli olmak için tespit edilen } 56 \text { yaşını } \\
\text { uygun bulmuyorum. }\end{array}$} & \multirow{2}{*}{$\begin{array}{c}\begin{array}{l}\text { Pearson } \\
\text { Chi-Square }\end{array} \\
\mathbf{X}^{2}\end{array}$} \\
\hline & \begin{tabular}{|c|c|} 
& \\
0 \\
0
\end{tabular} & 声 & 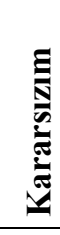 & 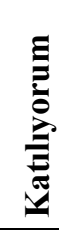 & 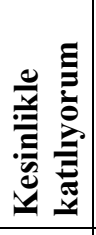 & $\stackrel{\bar{\sigma}}{\stackrel{\pi}{\theta}}$ & \\
\hline Evet & 5 & 3 & 13 & 25 & 22 & 68 & \multirow{3}{*}{0,161} \\
\hline Hayır & 23 & 18 & 38 & 44 & 44 & 167 & \\
\hline Toplam & 28 & 21 & 51 & 69 & 66 & 235 & \\
\hline
\end{tabular}

Tablo 19'daki sonuçlara göre; emekli olmak için belirlenen 56 yaş sınırını \%57,5'lik katılımcı kesimi uygun göememektedir. Önceki değerlendirmelerde 56 yaș sınırının katılımcıları tatmin ettiğini ifade etmiştik. Buradaki tutarsızlığın nedenlerinden birisi özellikle sisteme 45 yaş üzeri çalışanların katılmaması oranın yüksek çıkmasına yol açmıştır. Ayrıca ülke gündeminde erken yaşta emeklilik durumunun yoğun olarak gündemde olduğu bu dönemde katılımcı kişilerin 56 yaş sınırından memnun olmaması tabii bir olarak karşımıza çıkmaktadır. H5 hipotezi reddedilmiştir.

Tablo 20: Devlet Desteğinin Sisteme Katılım İsteğini Etkileme Durumu ile Sisteme Üyelik Durumu İlișkisi

\begin{tabular}{|c|c|c|c|c|c|c|c|}
\hline \multirow[b]{2}{*}{$\begin{array}{l}\text { Otomatik katılım } \\
\text { sistemine dahil } \\
\text { misiniz? }\end{array}$} & \multicolumn{6}{|c|}{$\begin{array}{l}\text { Devlet katkısı } \\
\text { arttırıyor. }\end{array}$} & \multirow{2}{*}{$\begin{array}{c}\text { Pearson } \\
\text { Chi-Square } \\
\\
\mathbf{X}^{2}\end{array}$} \\
\hline & $\begin{array}{ll} & \\
& \\
0 & \\
0\end{array}$ & E & 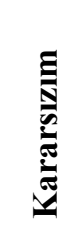 & E & 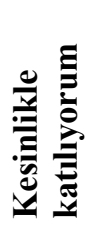 & $\stackrel{5}{0}$ & \\
\hline Evet & 7 & 5 & 13 & 28 & 15 & 68 & \multirow{3}{*}{0,000} \\
\hline Hayır & 36 & 34 & 44 & 44 & 9 & 167 & \\
\hline Toplam & 43 & 39 & 57 & 72 & 24 & 235 & \\
\hline
\end{tabular}

Tablo 20'deki sonuçlara göre, katılımcı bireylerin \% 54,9'u devlet katkısının önemini belirtmektedir. Fakat bireysel emeklilik sigortasına dâhil olanların oranının \% 28,9'da kalması sadece devlet katkısının yeterli olmadığını ifade etmektedir.. Bu durum desteğin sisteme katılımda yetersiz kaldığı sonucunu pekiştirmektedir. Tablo 20'de hesaplanan "ki kare" değerine göre H11 hipotezi kabul edilmiştir. 
Tablo 21: Katılımcıların Yaş Dağılımı ile Sisteme Üye olma Durumları İlişkisi

\begin{tabular}{|c|c|c|c|c|c|c|c|}
\hline \multirow{2}{*}{$\begin{array}{l}\text { Otomatik katılım } \\
\text { sistemine dahil } \\
\text { misiniz? }\end{array}$} & \multicolumn{6}{|c|}{ Yaş } & Pearson \\
\hline & $\begin{array}{c}\text { N } \\
\infty \\
\infty\end{array}$ & ఝి & $\frac{F}{\dot{f}}$ & 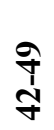 & $\begin{array}{l}\text { in } \\
\text { in } \\
\text { no }\end{array}$ & D: & $\mathbf{X}^{2}$ \\
\hline Evet & 2 & 34 & 22 & 7 & 3 & 0 & \multirow{3}{*}{0,442} \\
\hline Hayır & 11 & 90 & 37 & 15 & 12 & 2 & \\
\hline Toplam & 13 & 124 & 59 & 22 & 15 & 2 & \\
\hline
\end{tabular}

Tablo 21'deki sonuçlara göre, ankete katılanların \% 52,8'ini teşkil eden 26-33 yaş arası otomatik katılım sistemine katılma düzeyi \% 27,4 iken 34-41 yaş arası kesimi teşkil eden \% $25,1^{\prime}$ lik grupta bu oranın \% 37,2 olduğu görülmektedir. Katılımcı yaşları ile sisteme üyelik durumları bağımsız değişkenler olduğu "ki kare" oranına bakılarak ifade edilebilir. H1 hipotezi kabul edilmemiştir.

Tablo 22: Katılımcıların Cinsiyet Dağılımı ile Sisteme Üyelik Durumu İlişkisi

\begin{tabular}{|c|c|c|c|}
\hline \multirow{2}{*}{$\begin{array}{c}\text { Otomatik katılım } \\
\text { sistemine dahil misiniz? }\end{array}$} & \multicolumn{2}{|c|}{ Cinsiyet } & $\begin{array}{l}\text { Pearson } \\
\text { Chi-Square }\end{array}$ \\
\hline & Erkek & Kadın & $\mathbf{X}^{2}$ \\
\hline Evet & 34 & 34 & \multirow{3}{*}{0,100} \\
\hline Hayır & 103 & 64 & \\
\hline Toplam & 137 & 98 & \\
\hline
\end{tabular}

Tablo 22'deki sonuçlara göre ankete katılanların \% 58,3'lük kesimini teşkil eden erkeklerin \% 24'ünün sistemdeki üyelik durumlarının sürdüğünü gösterirken, kadınlarda bu oran \% 35,7'dir. Sisteme üyelik ile cinsiyet arasında bağımsız bir ilişkinin olduğu 0,100 değerle "ki kare" değerinden anlaşılmaktadır. $\mathbf{H 2}$ hipotezi reddedilir.

Tablo 23: Katılımcıların Medeni Durumu ile Sisteme Üyelik Durumu İlişkisi

\begin{tabular}{|c|c|c|c|}
\hline $\begin{array}{c}\text { Otomatik katılım } \\
\text { sistemine dahil misiniz? }\end{array}$ & \multicolumn{2}{|c|}{ Medeni durum } & $\begin{array}{l}\text { Pearson } \\
\text { Chi-Square }\end{array}$ \\
\cline { 2 - 3 } & Bekar & Evli & $\mathbf{X}^{\mathbf{2}}$ \\
\hline Evet & 23 & 45 & \multirow{2}{*}{0,292} \\
\hline Hayır & 45 & 122 & \\
\hline Toplam & 68 & 167 & \\
\hline
\end{tabular}

Tablo 23'deki sonuçlara göre medeni durumu bekâr olan katılımcılardan sisteme devam edenlerin oran $1 \% 33,8$ iken evli katılımc1larda bu oran \%26,9'a gerilemektedir.. Ancak "ki kare" değeri katılımcıların medeni durumları ile sisteme üyeliklerin bağımsız değişken konumunda olduğunu göstermektedir. Tablo 23'de yer alan "ki kare" değerine göre $\mathbf{H 3}$ hipotezi reddedilmiştir.

Tablo 24: Katılımcıların Sistem Hakkındaki Bilgi Durumu ile Sisteme Üyelik Durumu İlişkisi

\begin{tabular}{|c|c|c|c|}
\hline \multirow{2}{*}{$\begin{array}{c}\text { Otomatik katılım } \\
\text { sistemine dahil misiniz? }\end{array}$} & \multicolumn{2}{|c|}{$\begin{array}{c}\text { Zorunlu bireysel emeklilik sistemi } \\
\text { hakkında bilginiz var mı? }\end{array}$} & $\begin{array}{l}\text { Pearson } \\
\text { Chi-Square }\end{array}$ \\
\cline { 2 - 3 } & Evet & Hayır & $\mathbf{X}^{\mathbf{2}}$ \\
\hline Evet & 56 & 12 & \multirow{2}{*}{0,527} \\
\hline Hayır & 143 & 24 & \\
\hline Toplam & 199 & 36 & \\
\hline
\end{tabular}

Tablo 24'deki sonuçlar değerlendirildiğinde OKS hakkında katılımcı bireylerin \%84,7'si sistem hakkında bilgi sahibi olduğunu ifade etmiştir. Bu küçümsenmeyecek düzeyde bir orandır. Fakat bilgi sahibi olan bireylerin \%28,1'i sisteme üyeliklerini sürdürmektedir. Sistem hakkında 
yeterli bilgisi bulunmayan kişilerde ise bu oran \% 33'dür. "Ki kare" oranı değerlendirildiğinde $\mathbf{H 4}$ hipotezi reddedilmiştir.

\section{Sonuç ve Öneriler}

Sosyal güvenlik sisteminde meydana gelen finansman sıkıntıları kamu otoritesini yeni tedbirler almak zorunda bırakmıştır. Bu sebeple her devlet kendi koşullarını dikkate alarak yeni uygulamaları sürece dahil etmiştir. Ülkemizde de sosyal güvenliğin tamamlayıcı bir unsuru olarak düşünülen bireysel emeklilik sigortası bu çerçevede sürece katılmıştır. Fakat her uygulama bazen arzu edilen seviyede başarıyı elde edememektedir. $\mathrm{Bu}$ durumda öncelikle bir fizibilite çalışması yapılmalıdır. Böylelikle sistemin yürütülmesinde noksan vya hatalı yönler belirlenerek bu durumlar üzerine yeni ve daha kapsamlı bir çalışma ortaya konulabilir. Otomatik Katılım Sistemi katılımcı bireylerin beklentileri dikkate alınmadan 01/01/2017 tarihinde yeni çehresi ile karşımıza çıkmıştır. Fakat arzu edilen durum ile fiilile oluşan durum arasında fark önemli düzeydedir. $\mathrm{Bu}$ farkın nedenlerini belirleyebilmek ve çözüm tavsiyesinde bulunabilmek amacıyla 235 katılımcı birey ile gerçekleştirilen anket uygulamasının değerlendirme sonuçları özetlenecek olursa şu bulgular ortaya çıkmıştır denilebilir;

- Yapılan düzenlemeler yeterli seviyede olmamıştır, bu durum da katılımcıları sistemden uzaklaştırmıştır.

- Sistem, ilgili kişi veya kuruluşlar tarafında detaylı olarak anlatılmalıdır. Çünkü katılımcı bireyler kulaktan dolma bilgiler ile karar vermektedir.

- Sistemin otomatik katılımlı olması değiştirilerek bunun yerine teşvik edici yeni öneriler sunulmalıdır.

- Devlet desteği ile ilgili kişilerin dini noktada hassasiyetlerini gidermek önemlidir, katılımcı kişilerefaizsiz fon uygulaması hakkında bilgi verilmelidir

- Enflasyon oranındaki artışlara bağlı olarak devlet katkısında da değişiklikler yapılmalıdır. Enflasyon oranın yüksek seyrettiği bir zaman diliminde devlet katkısı oranının sabit kalması katılımcılar açısından problem teşkil etmektedir.

- Beklentiler daha gerçekçi olmalıdır.

- Sistemin kamu ekonomisine ve yatırımcıya sağlayacağı katkılar üzerinde durulmalıdır.

- Katılımcıların fonlar hakkında yeterli bilgiye sahip olmamasından dolayı fon çeşitleri katılımcılara iyi sunulmalıdır.

- Sistemden 10 yılını tamalamadan önce ayrılanlardan yapılan kesintilere düzenlemeler getirilmelidir.

- Fonların iyi değerlendirilebilmesi için danışma hizmeti devamlı şekilde sunulmalıdır.

- Fonlardan yapılan kesintilere bir düzenleme getirilmelidir.

- Bireysel emeklilik ve otomatik katılım sistemlerinin fon büyüklükleri zaman ilerledikçe hızlı bir şekilde artmaktadır. Bu bağlamda sisteme kaydedilen ve değerlendirilen fonların herhangi bir usulsüzlüğe uğramadan muhasebe süreçlerine ait işlemlerinin de muhasebe kuralları ve uygulamaları çerçevesinde izlenmelidir.

- Sistemde toplanan fonların uzman kişilerce nasıl yönetildiği ve ne kadar kazanç sağlandığı gibi konularda şeffaflık devamlı korunmalıdır.

Belirli bir kesimi ve belli bir bölgeyi esas alan bu çalışmadan sonra; daha geniş kapsamda Miili Eğitim Bakanlığı mensuplarının tamamını kapsayacak bir araştırma yapılabilir. Ayrıca özel sektör kesimini, banka sektörü kesimini veya akademisyenlerin sisteme bakışına yönelik amprik çalışmalar yapılabilir. Otomatik Katılım Sisteminin ülke ekonomisine katkısını konu alan çalışmalar da yapılarak bu konudaki çalışmalar zenginleştirilebilir. 


\section{Kaynakça}

Antolin, P. (2012). Coverage of Private Pension Systems: Evidence and Policy Option, OECD Working Papers on Finance, Insurance and Private Pensions, 20, 1-36.

Aydın, E. ve Kaplan, E. (2014). Bireysel Emeklilik Sisteminin Vergi Uygulamaları Bakımından Değerlendirilmesi, Marmara Üniversitesi İ.İ.B. Dergisi, 36(2), 93-114. http://hdl.handle.net/11424/5058

Büyükkara G.ve Balcı, M. (2014). "Bireysel Emeklilik Sisteminde Eski ve Yeni Teşvik Düzenlemeleri Üzerine Karş1laştırmalı Bir Değerlendirme." Mehmet Akif Ersoy Üniversitesi İktisadi ve İdari Bilimler Fakültesi Dergisi, 1(1), 37-53.

Frericks, P., Maier, R. ve De Graaf, W. (2007). European Pension Reforms: Individualization, Privatization and Gender Pension Gap. Social Politics: International Studies in Gender, State \& Society, 14(2), 212-237.

Holzmann, R. (2013). Global Pension Systems and Their Reform: Worldwide Drivers, Trends and Challenges, International Social Security Review, 66(2), 1-29.

Kara, S. ve Yıldız, Y. (2016). Türkiye'de Bireysel Emeklilik Sistemi: 2012 Sonrası Yapılan Reformlar ve Beklentiler, İşletme ve İktisat Çalışmaları Dergisi, 4(1), 23-45

Karagöz, Y. (2016). SPSS ve AMOS 23 Uygulamalı Istatistiksel Analizler. Nobel Akademik Yayıncilik.

Kartal, M. (2006). Bilimsel Araştırmalarda Hipotez Testleri 3.Baskı. Nobel Yayın Dağıtım.

Peker, İ. (2016). Analysing Turkish Individual Pension System Fees and Returns, Journal of Economics, Finance and Accounting, 3(1), 100-116.

https://dx.doi.org/10.2139/ssrn.2710627

Sezgin, S. ve Yıldırım, T. (2015). Türkiye'de Bireysel Emeklilik Sisteminin Etkinliği, Eskişehir Osmangazi Üniversitesi İ̈BF Dergisi, 10(2), 123- 140.

Yazıc1, S. (2015). Bireysel Emeklilik Sistemi ve Türkiye Uygulaması, Doktora Tezi, Ankara Üniversitesi Sosyal Bilimler Enstitüsü.

www.egm.org.tr/bilgi-merkezi/istatistikler/oks-istatistikleri, Erişim Tarihi 14.02.2020

www.egm.org.tr/bilgi-merkezi/istatistikler, Erişim Tarihi 14.02.20120

www.egm.org.tr/bilgi-merkezi/istatistikler, ErişimTarihi:.13.02.2020

www.egm.org.tr/otomatik-katilim/oks-nedir ErişimTarihi:13.02.2020

www.sigortaladim.com/uzman-gorusu/bes-cayma-hakki-sartlari, ErişimTarihi:15.01.2019

www.susehri.meb.gov.tr, Erişim Tarihi 20.09.2018

www.haberturk.com/bes-te-yeni-duzenleme-2273839-ekonomi, Erişim Tarihi 14.01.2019.

www.hsbc.com.tr, Erișim 09.01.2020. 